\title{
Queering the Ecclesia: Exploring "Institutional Culture" as a Path toward a Socially Just Church
}

\author{
Megan Robertson \\ https://orcid.org/0000-0002-2861-152X \\ University of the Western Cape \\ mrobertson@uwc.ac.za
}

\author{
Sarojini Nadar \\ https://orcid.org/0000-0001-8408-2557 \\ University of the Western Cape \\ snadar@uwc.ac.za
}

\section{Abstract}

Ecclesiological research on queer sexuality in South Africa has often been restricted to studying heteronormative church policies and doctrines as well as their implementation. This has confined possibilities of transforming church into a specifically queer affirming and more generally socially just space, to a matter of policy change. Similarly, transformation in higher education research in South Africa previously adopted a "transformation by numbers" approach centred on policy change. However, urgent calls to decolonise higher education has highlighted the limits of this "inclusive" approach and shifted the field's focus to an approach that interrogates the "institutional culture" of organisations to understand the ways in which such cultures might epistemologically and functionally preclude inclusion. Drawing on the case study of the Methodist Church of Southern Africa (MCSA), this paper proposes the extension and appropriation of the concept of "institutional culture" as it is used within higher education research for ecclesiological research, in order to expand queer possibilities of being a more socially just church.

Keywords: queer; ecclesiology; institutional culture; Methodist Church

\section{Introduction}

In February 2010, Reverend Ecclesia de Lange was fired from the Methodist Church of Southern Africa (MCSA) after declaring to her congregation her intention to marry her same-sex partner (Kotze and De Lange 2011). When the internal disciplinary procedures of the MCSA seemed to De Lange to be futile in challenging the church's decision to dismiss her, she sought the help of the secular courts. Her case stood before the High Court of the Western Cape, then the Supreme Court in Bloemfontein and

\section{UNISA}

Studia Historiae Ecclesiasticae https://unisapressjournals.co.za/index.php/SHE/index Volume 47 | Number 3 | 2021 | \#9466 | 16 pages https://doi.org/10.25159/2412-4265/9466 ISSN 2412-4265 (Online) ISSN 1017-0499 (Print) (C) The Author(s) 2021 
finally the Constitutional Court in 2015. In September 2017 she submitted an appeal to the Labour and Equality Court but later withdrew the case due to the immense personal sacrifice this would, and had already demanded from her, including the loss of her job and the dissolution of her first marriage. ${ }^{1}$ Throughout this process, and contrary to Elias Bongmba's claim that "legal and constitutional protections offer the best chance for gaining the rights of LGBTQ people in Africa" (Bongmba 2021, 130), the courts continually found in favour of the church and urged De Lange to seek arbitration within the bounds of the MCSA's own procedures. The ruling of the court stated that those "who voluntarily commit themselves to a religious association's rules and decisionmaking bodies should be prepared to accept the outcome of fair hearings conducted by those bodies" (Ecclesia de Lange v ... 2014, para 40). Whether a complaint is being lodged about clergy's sexual abuse, or a case is being made for the ordination of women, those making such cases often refer to church legislation, canon law or church policies, as if these are self-implementing. In fact, "rules and decision-making bodies" form a big component of ecclesiological research in South Africa on the subject of queer ${ }^{2}$ sexuality. Even when the focus of the research is not on rules and policies, it is on theological beliefs (Reygan 2016; Sistig and Nadar 2011), or the role of the Bible in either supporting or denying queer agency (Davids and Jones 2018; Thyssen 2020; Van der Walt 2016; West and Van der Walt 2019). The result has been that queer imaginings of a more just and inclusive church have largely been confined to the (im)possibilities of transforming church laws, policies, doctrines, theological beliefs and biblical interpretation.

We find that a comparable stagnation occurred in higher education research in South Africa in the late 90s, where transformation discourse was largely aimed at creating policies that would enable students of colour to access so-called previously "White universities." Initially, little attention was paid to how these incoming students would experience the university and it was taken-for-granted that they would simply have to assimilate. Over the past two decades, however, calls for decolonising higher education in South Africa has shifted higher education research from a focus on "institutional policy" to "institutional culture." This shift has helpfully broadened conceptualisations of "transformation" beyond inclusion policies, to critically consider the lived experiences of faculty and students in relation to race, class, gender, and sexuality. This epistemic shift has enabled scholars to seriously interrogate the social, cultural and epistemic systems in the university which hinder transformation, as well as to consider broader possibilities for social change. The value of "institutional culture" as a conceptual, methodological and analytic research tool seems to lie in its capacity to

1 This account of Ecclesia's case has been reconstructed based on an interview with one of the authors, Megan Robertson, in September 2018 at the University of the Western Cape. A more detailed account of De Lange's story is available at: https://iam.org.za/ecclesias-journey/.

2 Noting the politics, particularly in Africa, around the use of "queer" in this paper, we use it not only as a theoretical lens but also in reference to non-normative sexualities and gender non-conforming people. In this way, we are able to recognise the fluidity of identities and a range of gendered and sexuality performativities. 


\section{Robertson, Nadar}

critique different aspects of a complex system whereby institution and person interact in intricate and entangled ways that go beyond the legislated rules of engagement.

The purpose of this paper is to explore the value of the concept of "institutional culture" for its potential in expanding the ways in which we imagine queer possibilities for the church. We do this by drawing on the case study of the Methodist Church of Southern Africa (MCSA), as we present a critique of the limited ways in which scholars have envisioned the church's potential to be queered. We then go on to explore how conceptualising transformation and justice through the lens of "institutional culture" has been helpful in envisioning more socially just and inclusive universities that go beyond "improving" racial demographics. Finally, we draw out some of the strengths of institutional culture as a heuristic key in understanding the complex debates and suggest how it might be useful in advancing research that provides possibilities for transformation within the MCSA.

\section{Framing the Same-sex Debate in the MCSA}

In relation to decisions and questions around sexualities, which are constructed as nonnormative, the debate termed "the same-sex debate" in the MCSA has been a longstanding one. In 2001, at the MCSA Conference, the church communicated that it seeks to be a "community of love rather than rejection" (MCSA 2006, 225). At the Conference in 2003, the church was asked to engage on the topic of same-sex relationships using a discussion guide which offered six key principles for constructive debate, namely: 1) seek the truth of Christ in the spirit of Christ; 2) seek to move beyond "corners of conviction"; 3) seek first to understand, and then to be understood; 4) seek to see the human face of this issue; 5) seek to become well-informed; and 6) seek to celebrate the gift of diversity (MCSA 2003). The debate which this discussion guide facilitated, demonstrated perhaps what the MCSA had already known - that there are widely divergent beliefs held within the church. ${ }^{3}$ This prompted Conference in 2005 to commit the MCSA "... to an ongoing journey of discovering what it means to be part of a church that embraces many different and even opposing views on this issue" (MCSA 2006, 75), and to affirm that the entire church is "enriched and strengthened by the differing views and perspectives of its members" (MCSA 2006, 76). The Connexional Executive of 2006 directed that until Conference had pronounced on the matter, that "the MCSA continues to recognise marriage as only between a man and a woman, and urged ministers to refrain from officiating at same-sex unions" (MCSA 2007, 50).

Between 2007 and 2014, Conference continually urged clergy not to officiate at any same-sex unions but to offer pastoral counsel to "homosexual people"-an institutional position that continues up to the time of writing this article. It also continued to encourage Methodists to read the Bible study material, In Search of Grace and Truth:

3 Both views have been supported by theologians as is evidenced by the unpublished presentations delivered at a meeting of the Doctrinal, Ethics and Worship Committee of the MCSA in 2006. Accessed November 18, 2019. https://mcsadewcom.blogspot.com/. 
Christian Conversations on Same-sex Relationships ${ }^{4}$ (Attwell, Alistoun, and Scholtz 2010) and to propose concrete suggestions "as to how the divergence of conviction within the church on this issue can be exercised in ways that will preserve the integrity and unity of the church" (MCSA 2014, 215). Evident within the MCSA's debate, was the struggle to accept divergent positions on the issue, because it ostensibly goes against the denomination's integral call for unity. Central to this struggle were institutional questions about how a denomination remains unified when there exists a variety of differences in beliefs and understandings. Ndikho Mtshiselwa (2010b, 771) seemingly calls the church out on this "all interpretations matter" stance, when he argues that through the acceptance of different interpretations of Scripture, the MCSA ignores the fact that there are irresponsible and unethical interpretations and approaches to Scripture. In addition, he argues, the MCSA's ambiguous stance of embracing differing opinions seems to close off the doors of possibility for reaching a common consensus in understanding through responsible interpretations of Scripture (Mtshiselwa 2010a; 2010b). The MCSA's claim of being a community of love, rather than rejection, implies something about its hope of being a place of welcome and inclusivity for all people. Yet, thus far, in its stance against same-sex marriage and the ordination of queer people, it has failed to become inclusive even at the level of granting queer members access to the ministry or to marriage. De Lange's case reveals the very real consequences attached to being a queer person in the MCSA. For "womxn" of colour, the ways in which race, gender and class intersect with sexuality is even more punishing, as Megan Robertson's (2020) PhD thesis reveals. Yet, thus far, institutional debates and much of the scholarly discourse focusing on possibilities of the full inclusion of queer people in the MCSA, have not engaged seriously with the embodied and lived experiences of De Lange and other queer members.

Ndikho Mtshiselwa (2010a) produced the first significant academic engagement on the topic post-De Lange. Mtshiselwa's Master's dissertation (2010a) and subsequent article (2010b) analyse the MCSA's interpretations of Leviticus 18:22 and 20:13. He does this by offering a critique of the five DEWCOM contributions, previously mentioned, as well as DEWCOM's discussion document on same-sex relationships, in which the Wesley Quadrilateral is used as an approach in discussing homosexuality. Mtshiselwa brings this into conversation with Xhosa receptions of homosexuality as well as an analysis of the Leviticus texts through an African hermeneutical lens. Mtshiselwa (2010a, 133) critiques the MCSA discussions and African rejection of homosexuality based on conservative exegesis of texts and inculturation theologies as supporting underlying motives of "holiness and sound morals as well as the issue and/or concern for family orderliness ..." (Mtshiselwa 2010a, 133). Mtshiselwa concludes that consensus cannot be reached through Scripture alone but rather that to journey beyond the stalemate, areas of consensus and contestation, especially between Methodist

4 This book was written for the MCSA and provides reflective essays and questions which were designed to guide churches and groups in discussing their divergent positions on same-sex relationships. 
interpretations of Scripture and cultural understandings of sexuality, must be identified and debates should proceed from there.

Sifiso Khuzwayo (2011) seems to take a similar position. He is not advocating for a solution to the debate, in fact, he argues that because there are complex debates on the authority of Scripture, theologians do not have enough information to make any decision. He argues that the issue which threatens to break "ecclesiastical communities" in the MCSA is not the issue of homosexuality, but the church's lack of response (Khuzwayo 2011, 38). He thus suggests that the way forward involves the MCSA admitting that they do not have sufficient information (Khuzwayo 2011, 38). He further argues that systematic and "true liturgy" should inform the way forward and that "this can only be done if we resist the temptation of just standing our own ground and shift to a place where we can be found by Christ and helped to find each other" (Khuzwayo 2011, 39). He borrows the term Dihliz/Threshold, from Ghazali, a Muslim philosopher as conceptualised by Ebrahim Moosa (2005), to argue that the church needs to proceed from a place where all relevant viewpoints are given due recognition (Khuzwayo 2011, 34).

Raymond Simangaliso Kumalo (2011), another theologian from the Methodist Church, examines how the MCSA's missional response to apartheid (and its stance on various social justice matters thereafter) of being a "one and undivided" church remains valid when placed in the context of the "same-sex debate." Kumalo $(2011,187)$ explores how culture, theology and politics factor in to the division between those for and those against "homosexuality" - and particularly same-sex marriage. In terms of culture, he resorts to essentialist ideas of race to argue narrowly that "the influence of culture on the issue of same-sex marriage can be seen by the demographics of those who support and those who oppose it, with White people dominating the former group and Black people dominating the latter" (Kumalo 2011, 186). He argues similarly to Mthiselwa and Khuzwayo that Scripture is inconclusive, and that the interpretive frame theologians use can be employed to interpret it in a variety of ways. Last, on the matter of politics, he seems to conclude that the government is more prophetic than the church, but that politics and the church indeed disagree on the issue of homosexuality, however also diverge in that the one will not rule over the other. Echoing the scholars discussed previously, Kumalo $(2011,189)$ offers little new by way of theoretical insight, but emphasises that the MCSA needs to remain "one and undivided." He specifically emphasises this as the responsibility of leadership (read clergy), for in order to move the discussion forward the church should: 1) confess their sins and repent for inflicting suffering on gays and lesbians; 2) talk more openly about human sexuality and draw from social sciences, biology and philosophy as well as the Wesleyan quadrilateral; and 3) conscientise and educate its members.

Wessel Bentley (2012), in an article entitled "A Decade of the Same-sex Debate in the Methodist Church of Southern Africa (2001-2011)," provides a helpful sketch of the contours of the debates with a specific focus on same-sex marriage, rather than 
sexuality. Bentley too, also seems only able to recommend steps to moving the discussion further. He suggests that Christian identity should be the foremost identity in discussions on same-sex marriage and argues that "when we find consensus in people's primary location of identity, it creates a common ground from which a mutually accepted theology can be built" (Bentley 2012, 8). Second, he proposes drafting "a church confession which proposes first of all the Christian principles of diversity, dignity, humanity and justice" (Bentley 2012, 8).

The only published academic work which seems to urge for more substantial change from the MCSA has been written as a praxis piece by Judith Kotze and Ecclesia De Lange (2011), as they theorise the model De Lange put into practice to engage the MCSA and to promote transformation. The authors trace how De Lange's strategy of engaging the MCSA is a practical example of the Wheel of Catalyst Change strategy, which employs a circular loop of "empowerment, opening minds, opening hearts and opening doors" (Kotze and De Lange 2011, 204). Without repeating the process here, this article does highlight the impact that clergy can have on debates around sexuality in the church. The contribution also emphasises the agency of clergy to "empower" themselves.

All the scholars reviewed above, focus on critically engaging ecclesiological and missional ideas of what the church should be in relation to an examination of biblical Scripture or more general concepts of social justice. They also provide a necessary critique of the MCSA's ambivalence thus far. However, they also all seem to err on the side of caution. None of the scholars discussed above have gone beyond mapping out the principles that should guide the debate. Further, none have come to the point of suggesting or exploring a queer theology or religiosity, as other scholars such as Jodi O'Brien (2004), Michael Keenan (2008), and Adriaan van Klinken (2015) have done for other church contexts and denominations in other countries. Perhaps the reason for their collective cautionary stances lies in Kumalo $(2011,176)$ and Bentley's $(2012,7)$ claims that the church should not rush if its aim is to "maintain unity." The emphasis in the scholarship on maintaining unity can perhaps be attributed to the fact that most of those writing on this topic in the MCSA, are themselves Methodist clergy or leaders and thus echo the institutional agenda to remain "one and undivided." While religious and ecumenical discourses of unity often carry positive connotations, as we argue later in this article, they can also be associated with motivations to maintain organisational power (Higgins 2007). As Fulata Moyo and Sarojini Nadar (2012, 236) point out, concerns with "unity of the church" remain one of the biggest hindrances to gender justice. They note that in debates like these, "justice" often loses to unity. They argue that "... the issue of justice gets sacrificed on the altar of unity, or ... peace. [s]o, to maintain peace between particular denominations, or to secure unity, we 'dumb-down' issues of justice-particularly gender justice." The lack of more transformative arguments by Methodist scholars, therefore, reflects the institutional agenda not only to maintain unity, but power. It is perhaps also reflective of underlying motivations that 
their own investments in the church structure and belief systems, as well as the power that lies in its prodigious church membership, should continue unruptured.

It seems then that conceptual, theoretical and methodological tools beyond those that simply support narrow ideas of "ecclesial unity" are needed, in order to engage more meaningfully with a debate that has essentially stagnated. We thus turn to the concept of "institutional culture" as used by educationalists in South Africa, as a potential guide for researchers to uncover the practicalities between arguing for a narrow inclusivity through policy, doctrine and biblical interpretation and a radical transformative socially just church.

\section{Conceptualising "Institutional Culture": Bridging the Gap between Inclusivity and Transformation}

Over the past two decades, higher education institutions (HEI's) in South Africa have increasingly come under pressure to make numerous changes in their recruitment, retention and study programmes. This pressure was largely exerted by the Soudien Report released in 2008 (with reference to the chairperson of the committee, Professor Crain Soudien), which followed a highly publicised incident at the University of the Free State in which a few young, White, male students were accused of vilifying Black workers of the university by making them participate in derogatory acts such as eating food which had been urinated on. This, along with urgent calls by Fallist student movements to decolonise higher education, pressurised HEIs to create transformative practices which grant access to students from previously disadvantaged backgrounds. Despite many previously White universities implementing extensive recruitment policies to grant access and support to more students of colour, research has consistently shown that informal segregation continues to inform interactions in South Africa and on university campuses (Ballard 2004; Dixon and Reicher 2011; Pattman and Carolissen 2018). This occurs even when the numerical demographics of the student populations in institutions are more representative and reflective of the breakdown of the population in South Africa in terms of race, class and religion, as for example at the University of KwaZulu-Natal (see Pattman 2010).

Recognising that numerical inclusivity was not enough, scholarship began to shift from "institutional policy" research to "institutional culture" research. Institutional culture has been conceptualised as "the prevailing ethos - the deep-seated set of norms, assumptions and values that predominate and pervade most of the environment" (Steyn and Van Zyl 2001, x). It is the "way we do things around here" (Jansen 2004, 122), the "way of life" of the university. Through lived experience, those who join the university come to know it. The concept has been helpful in making visible and critiquing the overwhelming Whiteness (beyond demographics) of HEI's, which come to be experienced as marginalising and alienating for those who do not seem to find "home" in the normative way of life (Higgins 2007). This has encouraged HEIs to look beyond their policies and call into question some of the taken-for-granted ways in which 
students who do not fit the norm are excluded and negatively affected academically and otherwise by the culture of the institution.

Examining the taken-for-granted sexual norms of a church that seeks to be a place of "community of love rather than rejection" is also a good starting point for ecclesiological research on the subject of sexual diversity. We believe that examining the MCSA through the lens of institutional culture can serve to make visible and critique the normative ways of being church, and the experiences of exclusion that both official and social exclusion may cause members who do not find "home" in the church. Institutional culture research may prove useful for the MCSA (and other denominations struggling with stagnation) through its ability to: 1) make visible and critique taken-forgranted systems of power; 2) theorise the lived experiences of its members in relation to systems of power; 3) account for the complexity of transformation in institutions; and 4) provide a transformative concept of change.

\section{Making Visible and Critiquing taken-for-granted Norms}

Within higher education research one of the most significant advantages of framing transformation within "institutional culture" terms, has been its ability to name and critique the overwhelming Whiteness of higher education, which has remained, regardless of the demographic makeup of the institution. One of the foremost examples of this is Melissa Steyn and Mikki van Zyl's (2001) study of the University of Cape Town (UCT), "Like that Statue at Jammie Stairs ..." In their study they produced data by exploring student experiences of the university and argued that the institutional culture of UCT had been shaped by "a very specific historical cultural positioning" and an entrenched normative ideology (Steyn and Van Zyl 2001, iii). For Steyn and Van Zyl $(2001,68)$, it is the lack of attention paid to institutional culture which brings about and leaves unquestioned a "culture of Whiteness." The central and repeated point - of "Whiteness" as the "invisible norm"- offers a powerful new perspective on the institutional cultures of South African universities. For educationalists, the project of transformation has involved an intensive consciousness-raising exercise to examine and question the "normal" (Steyn and Van Zyl 2001, 29).

Similarly, we argue, bringing the tools of institutional culture research to bear on "takenfor-granted" norms such as heteronormativity can be a more helpful starting point for understanding the "same-sex debate" in the MCSA than doctrinal and scriptural "policy" research, which presumes a stability of norms.

\section{Theorising Lived Experience in Relation to Systems of Power}

Many scholars have acknowledged the challenges of identifying and measuring institutional culture. The assumption when studying institutions of higher education, as well as ecclesiological research on the church, has been that institutions can be (and should be) studied outside of the lives of those who are in them. Thus, research has focused exclusively on the level of policy, rules and decision-making bodies. On the 
other hand, institutional culture has been conceptualised as something which those entering into the culture assimilate to, dis-identify with, negotiate and navigate. Thus, it is through exploring lived experiences that the entrenched institutional culture can be understood. It is also through lived experience that research can uncover agency, resistance, and disruption, thereby uncovering possibilities of transformation. This is why we must take Steyn and Van Zyl's $(2001,2)$ claim, that "nothing can be achieved without understanding the sense-making of the students themselves," very seriously, and the implication of this for ecclesiological research is that the "sense-making" of clergy and parishioners alike, are equally important in any assessment that one makes of the church.

John Higgins $(2007,108)$ points out that it is not enough to try to understand institutions through lived experience alone, but that institutional culture is related to systems of power. For Thaver $(2006,21)$, institutional culture "becomes evident in the social relations that circulate power, in the social networks that gather power, in the symbolic which congeals power, and in the imaginary which wills power." It is, therefore, theoretically and methodologically important that academic ventures into institutional culture should take cognisance of how lived experiences relate to structural and ideological systems of power, which together shape and dismantle institutional culture. It is also important to pay attention to the critique of studies such as those of Steyn and Van Zyl's (2001), which focus exclusively on one system of power to frame multiple experiences. Thus, it would be important for institutional culture research on the church to consider a variety of intersecting normativities such as ableness, Whiteness, and patriarchy, which stand at the core of church culture to frame a variety of everyday experiences.

By fixing ecclesial research on policy and doctrine alone, to the exclusion of queer clergies' lived experiences, research has ironically been unable to shift the actual policies, let alone transform the theologies which undergird them. Recently, Megan Robertson's (2020) doctoral thesis has taken on this issue by exploring the lived experiences of queer clergy in the MCSA. Her analysis incorporates theories of power, belonging, embodiment, domesticity and transformation and begins to reveal and critique the heteronormative institutional culture of the MCSA. The conversations which Robertson's work opens up, provide important insight into the considerations for the politics and institutional cultural dynamics that impact upon transformative and affirming policies, theologies, laws as well as the informal everyday ways in which things are done in the MCSA.

\section{Accounting for the Complexity of Institutions}

Institutional culture has been described as "a hard to define phenomenon" (Jansen 2004, 1) and a "slippery notion indeed" (Ensor 2006, 188). However, it is this slipperiness that holds space for any and every aspect of experience at university, "from parking to policing, from the sites and names of buildings to any and every joke told on campus" (Steyn and Van Zyl 2001, 42). Although this may seem to be asking too much from one 


\section{Robertson, Nadar}

concept, it reflects the nuanced complexities of analysing and changing institutional culture. It is important to note that institutional culture research may come to name different aspects of the same institution, depending on what questions the researcher seeks to answer and through which lenses they seek to find those answers (Higgins 2007, 114). Admittedly, this has meant that some higher education studies around institutional culture have been relegated to the examination of policies and structures, rather than experience and power (Jacobs 2012; 2016). However, this multiplicity of meaning compels institutional culture research to be intersectional in its analysis and intellectually humble in any contribution it makes to transformation discourse.

Certainly, recognising the church as a complex institution is not new in theological research. However, recognising its institutionalism as monolithic and almost unchanging has been a hallmark of the study of ecclesiology in general, but more particularly, studies on queer theology and the MCSA has reflected this lack. The scholarly research itself has concerned itself with "unity" or with "balance"; thereby almost erasing the many ways in which the church is largely heterogeneous in character.

\section{A Transformative Concept of Change}

Although using the lens of institutional culture compels humility, it does imply that institutions are cultural entities, and are thus not fixed but changeable. Studies focusing on institutional culture have warned against using it as a colonising concept of change rather than a transformative one (Higgins 2007, 105). The danger of this is real when considering that it derives its origins from studies on organisational culture, which aimed to assist management in promoting a unified organisational culture to which everyone joining the organisation would need to subscribe. This often takes the form of management imposing policy and structural change, which reflects a common vision, ideologically driven by the realities of those on decision-making bodies.

Institutional culture research has aimed to subvert this traditional model of change in order to promote a more transformative pathway to change. Its critique is that an exclusive decision-making body cannot define or guide institution-wide change processes (Simsek and Louis 1994, 691). This is evidenced by the fact that for many years the culture and value system of higher education institutions remained relatively intact, despite policy changes and even when students and staff from diverse backgrounds and with differing worldviews began to enter. An obvious reason for this is that those entering the institution were largely treated as guests, while decisionmaking bodies and others who met the norms and occupied positions of power, made themselves at home (Thaver 2006). Institutional culture thus advocates for a more decentralised means of change, which considers the diverse and sometimes competing ways of being, in different areas and structures of the institution.

Similarly, feminist theologians have repeatedly made cases for moving beyond the struggle of women's inclusion in a patriarchal church leadership hierarchy, to seeking to transform the institutional culture present in the ecclesial systems (see Green 2009; 
Percy 2014; Russell 1993). Studying ecclesial culture in this way, is a step towards queering the ecclesia, we argue.

\section{Moving toward a Queerer Church through Engaging with its Institutional Cultures}

One of the pitfalls of current ecclesiological scholarship, and queer theology, is that it tends to deploy a vocabulary that represents possible change as an organic or even obvious process which follows from policy and structural change, or theological reinterpretation. Linn-Marie Tonstad $(2015,15)$ posits that even where church contexts have opened to same-sex marriage and ordination, scholars have tended to look to "a gloriously queer future of inclusivity and radical boundary crossing" and have neglected opportunities to explore the complexities of how this inclusivity may come about. The need for a shift in focus is most perceptibly evident in feminist theological scholarship after the struggle for women's ordination was won. Feminist scholars of religion then started documenting the myriad of challenges that ordained women faced in an unchanged patriarchal institution that still operated like an "old boys' club" (see Phiri and Nadar 2005; Watson 2002). As such, the focus in their scholarship shifted from making a case for the ordination, and thereby the inclusion of women, to making a case for the transformation of ecclesial structures. Similarly, Sarojini Nadar and Adriaan van Klinken $(2018,104)$, in their paper on queering the theological and religious studies curriculum, also make a case for moving beyond an "inclusive" paradigm; and they recognise how such inclusive paradigms have "been criticized by several scholars in queer pedagogy as a form of 'assimilationist politics' - a strategy that seeks to expand the definition of normal to include LGBT people." They cite the work of Susanne Luhmann's helpful critique of inclusion that instead of "attacking and undermining the very processes by which (some) subjects become normalized and others marginalized" such inclusive paradigms reinscribe the norms of the system that have been exclusionary to begin with.

There is also evidence of this within research on the MCSA. Jenny Sprong (2011), Raymond Kumalo (2016), Phemelo Marumo (2016) and Luvuyo Sifo (2016) have brought about strong critiques that, although the church has equal policies and laws about welcoming women into its fold, certain practices, policies, hymns, and liturgy still have patriarchal roots and continue to serve to exclude women from taking up equal leadership positions and serving equally as men do. Despite sometimes relying on essentialist understandings of gender to make these arguments, the ecclesiological scholarship on the MCSA remains important to note as it suggests that even though policy has changed, attitudes, beliefs and practices remain entrenched in the church.

While they may not have used "institutional culture" as a framing for their research, there was an overwhelming focus on the multiple social and cultural norms that hampered women's leadership, and using the framing of institutional culture research could have supported the quest to better understand the church as a complex and 


\section{Robertson, Nadar}

disputed social institution. In other words, exploring the church's institutional culture, rather than only its policies and doctrines, enables an exploration of different aspects of an intricate and intersectional system whereby institution and individual interact in complex ways. The lessons learned from the shifts in feminist ecclesiological research are valuable for queer ecclesiological research too. Transformation, through the lens of institutional culture, recognises that top-down transformation is implicated in the institutional culture itself. In other words, the taken-for-granted norms are taken-forgranted even by those who would like to see change. Thus, if research is to work beyond just an inclusive church to a more socially just and transformative church-it must work towards understanding the agentive power of the church's members - and especially its queer members and how they point out, shape and challenge the normative structures and ways of doing things in the church.

\section{Conclusion}

In 2001, the MCSA made a claim to be a "community of love rather than rejection." However, little conscious change has taken place to make this statement an ecclesial reality. Research focusing on the MCSA has thus far concerned itself with setting forth principles from which to proceed with the debate. Although many have recognised that people are marginalised, and while policy debate moves slowly, few have sought to explore what "being a community of love" rather than rejection might look like. In order to move this debate forward, we have suggested the incorporating of aspects of institutional culture research into a conceptualisation of queer ecclesiology.

In higher education, institutional culture developed from the need to recognise that inclusivity in terms of representative demographics and policies was not enough to direct change towards transforming an institution into a place that feels like "home" for a diverse group of people. This type of research has proved useful in exploring the complex ways in which institutional cultures are shaped by unacknowledged systems of power in which some are seemingly able to "naturally" flourish, while others are pushed to the margins.

Extending this conceptual lens into the realm of ecclesiological research encourages us to first proceed from the everyday experiences of queer clergy and parishioners in order to understand what systems of power shape institutional church culture and how different people navigate, co-construct and resist it in various spaces of the organisation. By exploring the ways in which normative systems become entrenched and disrupted, the possibilities of moving toward a more transformative, queer affirming church become possible. We do not mean to suggest here that a critique of policy is not important for inclusion and radical change, nor do we claim that a focus on institutional culture will be a panacea for all issues of transformation in the church. However, for the MCSA and other denominations seeking to become truly inclusive of queer, women and all other members, bringing institutional culture research to bear on conventional ecclesiological studies may sharpen our ability to address the ways in which the church 
can indeed be a place of radical social justice, instead of rejection and ecclesial stagnation.

\section{Acknowledgements}

This article is based on research supported by the National Research Foundation of South Africa (Grant number: 118854). The authors acknowledge that opinions, findings, and conclusions expressed are those of the authors alone, while the NRF accepts no liability whatsoever in this regard.

\section{References}

Attwell, Tim, Ray Alistoun, and Roger Scholtz. 2010. In Search of Grace and Truth: Christian Conversations on Same-sex Relationships. Cape Town: Cingela Press.

Ballard, Richard. 2004. “Assimilation, Emigration, Semigration and Integration: 'White' People's Strategies for finding a Comfort Zone in Post-apartheid South Africa." In Under Construction: "Race" and Identity in South Africa Today, edited by Natasha Distiller and Melissa Steyn, 51-66. Johannesburg: Heinemann.

Bentley, Wessel. 2012. "A Decade of the Same-sex Debate in the Methodist Church of Southern Africa (2001-2011).” Studia Historiae Ecclesiasticae, Vol. 38: 205-220.

Bongmba, Elias. 2021. "Same-Sex Relations and Legal Traditions in Cameroon and South Africa." Journal of Law and Religion 36 (1): 130-147. https://doi.org/10.1017/jlr.2021.6.

Davids, H., and C. Jones. 2018. "Theological-ethical Contours for the full Inclusion of LGBTIQ+ Bodies in the Church." In Justice-based Ethics: Challenging South African Perspectives, edited by C. Jones. Durbanville: AOSIS, 89-120. https://doi.org/10.4102/aosis.2018.BK77.04.

Dixon, John, and Steve Reicher. 2011. "Intergroup Contact and Desegregation in the new South Africa.” British Journal of Social Psychology 36 (3): 361-381. https://doi.org/10.1111/j.2044-8309.1997.tb01137.x.

Ecclesia de Lange $v$ The Presiding Bishop of the Methodist Church of Southern Africa (726/13). 2014. 151 (ZASCA).

Ensor, Paula. 2006. “Curriculum.” In Transformation in Higher Education: Global Pressures and Local Realities, edited by Nico Cloete, Peter Maassen, Richard Fehnel, Teboho Moja, Trish Gibbon, and Helene Perold, 179-193. Netherlands: Springer.

Green, Alison. 2009. A Theology of Women's Priesthood. London: SPCK.

Higgins, John. 2007. "Institutional Culture as Keyword." In Review of Higher Education in South Africa: Selected Themes, 97-122. Pretoria: The Council on Higher Education. 


\section{Robertson, Nadar}

Jacobs, Anthea. 2012. “A Critical-Hermeneutical Inquiry of Institutional Culture in Higher Education.” PhD thesis, Stellenbosch University.

Jacobs, Anthea. 2016. "Using a Theoretical Framework of Institutional Culture to Analyse an Institutional Strategy Document." Education as Change 20 (2): 204-220. https://doi.org/10.17159/1947-9417/2016/944.

Jansen, Jonathan. 2004. "Race and Education after Ten Years: Conversations." Perspectives in Education 22 (1): 117-128.

Keenan, Michael. 2008. "Religion as Enabler and Constraint in the Lives of Gay Male Anglican Clergy." In Religion and the Individual: Belief, Practice, Identity, edited by Abby Day, 169-181. New York: Ashgate Publishing.

Khuzwayo, Sifiso. 2011. "God or Caesar: A Queer Debate on Interpretation in the South African Church." Journal of Gender and Religion in Africa 17 (2): 24-40.

Kotze, Judith, and Ecclesia de Lange. 2011. "Suspended, Disciplined and Discontinued: A Practical Response towards Inclusion.” Journal of Gender and Religion in Africa 17 (2): 192-204.

Kumalo, Raymond Simangaliso. 2011. "'Us and Them' in the One and Undivided Church: The Methodist Church and the Same-sex Sexuality Debate." Journal of Gender and Religion in Africa 17 (2): 175-191.

Kumalo, Raymond Simangaliso. 2016. "From Constance Oosthuizen to Purity Malinga: The Struggle for Equality in Ordination in the Methodist Church of Southern Africa." Studia Historiae Ecclesiasticae 42 (2): 174-190. https://doi.org/10.17159/2412-4265/2016/1413.

Marumo, Phemelo O. 2016. "A Call for the Recognition and Empowerment of Women in Ministry in the Methodist Church of Southern Africa." Studia Historiae Ecclesiasticae 42 (3): 55-70. https://doi.org/10.25159/2412-4265/1504.

Methodist Church of Southern Africa. 2003. "Guidelines for the Use of the Conference 2003 Document on the Issue of Same-sex Relationships." Accessed November 12, 2019. https://www.smms.ac.za/wp-content/uploads/2019/08/christians-and-same-sexrelationships-conference-2003.pdf.

Methodist Church of Southern Africa. 2006. 2006 Yearbook. Cape Town: Methodist Publishing House.

Methodist Church of Southern Africa. 2007. 2007 Yearbook. Cape Town: Methodist Publishing House.

Methodist Church of Southern Africa. 2014. 2014 Yearbook. Cape Town: Methodist Publishing House. 


\section{Robertson, Nadar}

Moosa, Ebrahim. 2005. Ghazali and the Poetics of Imagination. Chapel Hill: The University of North Carolina Press.

Moyo, Fulata, and Sarojini Nadar. 2012. "Editorial: Gendered Perspectives on the Busan 10th Assembly Theme on Justice and Peace.” Ecumenical Review 64 (3): 233-240. https://doi.org/10.1111/j.1758-6623.2012.00170.x.

Mtshiselwa, Ndikho. 2010a. "Leviticus 18:22 and 20:13 in Discussion with the Methodist Church of Southern Africa." MA dissertation, University of Pretoria.

Mtshiselwa, Ndikho. 2010b. "How the Methodist Church of Southern Africa Read Leviticus 18:22 and 20:13 in View of Homosexuality." Old Testament Essays 23 (3): 769-787.

Nadar, Sarojini, and Adriaan van Klinken. 2018. "Queering the Curriculum: Pedagogical Explorations of Gender and Sexuality in Religion and Theological Studies." Journal of Feminist Studies in Religion 34 (1): 101-109. https://doi.org/10.2979/jfemistudreli.34.1.16.

O’Brien, Jodi. 2004. "Wrestling the Angel of Contradiction: Queer Christian identities." Culture and Religion 5 (2): 179-202. https://doi.org/10.1080/143830042000225420.

Pattman, Rob. 2010. 'Investigating 'Race' and Social Cohesion at the University of KwaZuluNatal.” South African Journal of Higher Education 24 (6): 953-971.

Pattman, Rob, and Ronelle Carolissen. 2018. Transforming Transformation in Research and Teaching at South Africa Universities. Stellenbosch: SUN PReSS. https://doi.org/10.18820/9781928480075.

Percy, Emma. 2014. Mothering as a Metaphor for Ministry. Farnham: Ashgate.

Phiri, Isabel, and Sarojini Nadar (Eds). 2005. On Being Church: African Women's Voices and Visions. Geneva: World Council of Churches.

Reygan, Finn. 2016. “'Love the Sinner, not the Sin?' Sexual and Gender Diversity in Faith Communities.” HTS Teologiese Studies/Theological Studies 72 (1): 1-5. https://doi.org/10.4102/hts.v72i1.3471.

Robertson, Megan. 2020. “Called and Queer: Exploring the Lived Experiences of Queer Clergy in the Methodist Church of Southern Africa." PhD thesis, University of the Western Cape.

Russell, Letty M. 1993. Church in the Round: Feminist Interpretation of the Church. Louisville: Westminster/John Knox Press.

Sifo, Luvuyo. 2016. "Implications of the Ordination of Women for the Methodist Church of Southern Africa." Studia Historiae Ecclesiasticae 42 (2): 156-173. https://doi.org/10.25159/2412-4265/1337; https://doi.org/10.17159/2412-4265/2016/1337. 
Simsek, Hasan, and Karen S. Louis. 1994. "Organizational Change as Paradigm Shift.” Journal of Higher Education 65 (6): 670-695. https://doi.org/10.2307/2943824.

Sistig, J., and S. Nadar. 2011. "Who's in Charge in a Genderless Marriage? A Feminist Queer Analysis of Opposition to Same-sex Marriage by the Marriage Alliance of South Africa." Journal of Gender and Religion in Africa 17 (2): 77-92.

Sprong, Jenny. 2011. "For Healing and Transformation: A Feminist Ecclesiological Study on the Gap between Gender Policy and Practice in the MCSA." PhD thesis, University of KwaZulu-Natal.

Steyn, Melissa, and Mikki van Zyl. 2001. “Like that Statue at the Jammie Stairs...”: Some Student Perceptions and Experiences of Institutional Culture at the University of Cape Town in 1999. Cape Town: iNCUDISA.

Thaver, Lionel. 2006. “'At home’ Institutional Culture and Higher Education: Some Methodological Considerations.” Perspectives in Education 24 (1): 15-26.

Thyssen, Ashwin. 2020. "Children of God: Exploring URCSA's Catechetical Sexual Ethic." Studia Historiae Ecclesiasticae 46 (3): 1-12. https://doi.org/10.25159/2412-4265/6954.

Tonstad, Linn Marie. 2015. "The Limits of Inclusion: Queer Theology and its Others." Theology and Sexuality 21 (1): 1-19. https://doi.org/10.1080/13558358.2015.1115599.

Van der Walt, Charlene. 2016. 'Is 'Being Right' more important than 'Being Together'? Intercultural Bible Reading and Life-giving Dialogue on Homosexuality in the Dutch Reformed Church, South Africa." In Christianity and Controversies over Homosexuality in Contemporary Africa, edited by Ezra Chitando and Adriaan van Klinken, 125-137. London: Routledge. https://doi.org/10.4324/9781315571928-9.

Van Klinken, Adriaan. 2015. “'Queer' Love in a 'Christian Nation': Zambian Gay Men Negotiating Sexual and Religious Identities." Journal of the American Academy of Religion 83 (4): 947-964. https://doi.org/10.1093/jaarel/lfv073.

Watson, Natalie. K. 2002. Introducing Feminist Ecclesiology. London: Sheffield Academic Press.

West, Gerald, and Charlene van der Walt. 2019. "A Queer (beginning to the) Bible." Concilium: International Journal for Theology, Vol. 5: 109-118. 